\title{
Aurantimonas ureilytica sp. nov., isolated from an air sample
}

Hang-Yeon Weon, ${ }^{1}$ Byung-Yong Kim, ${ }^{2}$ Seung-Hee Yoo, ${ }^{2}$ Jae-Ho Joa, ${ }^{3}$
Ki Hwan Lee, ${ }^{4}$ Yong-Seon Zhang, ${ }^{2}$ Soon-Wo Kwon ${ }^{2}$ and Bon-Sung Koo

\author{
${ }^{1}$ Applied Microbiology Division, National Institute of Agricultural Science and Technology, \\ Rural Development Administration (RDA), Suwon 441-707, Korea \\ ${ }^{2}$ Korean Agricultural Culture Collection, Microbial Genetics Division, National Institute of \\ Agricultural Biotechnology, RDA, Suwon 441-707, Korea \\ ${ }^{3}$ National Institute of Subtropical Agriculture, RDA, Jeju 690-150, Republic of Korea \\ ${ }^{4}$ Taean Lily Experimental Station, Chungnam Provincial Agricultural Research and Extension \\ Services, Taean 357-952, Republic of Korea \\ ${ }^{5}$ National Institute of Highland Agriculture, RDA, Pyongchang 232-955, Republic of Korea
}

The genus Aurantimonas, with Aurantimonas coralicida as the type species, was proposed for an isolate from a diseased colony of the scleractinian coral Dichocoenia stokesi (Denner et al., 2003). A second species, Aurantimonas altamirensis, was proposed recently for an isolate from a subterranean environment (Jurado et al., 2006). With the genus Fulvimarina, isolated from marine environments (Cho \& Giovannoni, 2003), this genus took up a distinct phylogenetic position separable from the other families within the order Rhizobiales. Thus, these two genera were classified into an eleventh family within the order Rhizobiales of the Alphaproteobacteria, the family Aurantimonadaceae.

Abbreviation: $\mathrm{PHB}$, poly- $\beta$-hydroxybutyrate.

The GenBank/EMBL/DDBJ accession number for the 16S rRNA gene sequence of strain $5715 \mathrm{~S}-12^{\top}$ is DQ883810.

A transmission electron micrograph of a cell of strain $5715 \mathrm{~S}-12^{\top}$, polar lipid profiles of strain 5715S-12 ${ }^{\top}$ and related strains and a $16 \mathrm{~S}$ rRNA gene sequence-based maximum-parsimony tree are available as supplementary material with the online version of this paper.
In the course of the study of bacterial strains isolated from air samples, we isolated a yellow-coloured bacterium, 5715S-12 ${ }^{\mathrm{T}}$. The air samples were collected with an MAS100 air sampler (Merck) (single-stage multiple-hole impactor) in Suwon city, Korea, on 15 July 2005. The sampler contained Petri dishes with R2A agar (BBL) amended with $200 \mu \mathrm{g}$ cycloheximide $\mathrm{ml}^{-1}$ (Sigma). After sampling, plates were incubated at $28{ }^{\circ} \mathrm{C}$ for 5 days.

For phenotypic characterization, R2A medium was used as the basal medium. For transmission electron microscopy, cells were grown for $48 \mathrm{~h}$ on R2A medium, negatively stained with $0.5 \%(\mathrm{w} / \mathrm{v})$ uranyl acetate and examined with an LEO model 912AB electron microscope. Gram staining, catalase, oxidase, poly- $\beta$-hydroxybutyrate (PHB) formation and hydrolysis of casein, DNA, pectin and starch were determined by the method of Smibert \& Krieg (1994). Hydrolysis of CM-cellulose $(0.1 \%$, w/v), chitin ( $1 \%$, w/v) and tyrosine $(0.5 \%, \mathrm{w} / \mathrm{v})$ was tested by the appearance of clear zones around colonies. Temperature, salinity and $\mathrm{pH}$ ranges for growth were tested over the ranges of $5-45{ }^{\circ} \mathrm{C}$, 
$0-10 \%(\mathrm{w} / \mathrm{v}) \mathrm{NaCl}$ and $\mathrm{pH} 4.0-10.0$. Pigment analysis was performed as reported by Denner et al. (2003). Further biochemical characteristics were determined using the API 20NE, API ID 32GN and API ZYM systems, following the instructions of the manufacturer (bioMérieux).

Isoprenoid quinones were extracted from lyophilized cells and analysed by HPLC as described previously (Groth et al., 1996). Polar lipid profiles were determined according to the methods of Minnikin et al. (1984). Whole-cell fatty acids were analysed according to the standard protocol of the MIDI/Hewlett Packard Microbial Identification System (Sasser, 1990) after cultivation on marine agar 2216 (MA; Difco) for 3 days at $28{ }^{\circ} \mathrm{C}$. The DNA G $+\mathrm{C}$ content was measured according to Mesbah et al. (1989) using a reversed-phase column (Supelcosil LC-18S; Supelco).

The 16S rRNA gene of the isolate was amplified by a PCR and sequenced directly using an ABI Prism 310 Genetic Analyzer (Applied Biosystems). The closest known relatives of the novel isolate were determined by performing GenBank/EMBL/DDBJ database searches. The software package MEGA version 3.1 (Kumar et al., 2004) was used for all analyses. Distances (using distance options according to Kimura's two-parameter model) and clustering using the neighbour-joining and maximum-parsimony methods were determined by using bootstrap values based on 1000 replicates.

Strain $5715 \mathrm{~S}-12^{\mathrm{T}}$ grew on R2A, MA, nutrient agar (Difco) and tryptic soy agar (Difco), but did not grow on MacConkey agar (Difco). Colonies were yellow, round and convex with clear margins after 3 days on R2A. Cells were short rods with more than one polar flagellum (Supplementary Fig. S1 available in IJSEM Online). Strain $5715 \mathrm{~S}-12^{\mathrm{T}}$ yielded carotenoid pigments with peaks in the absorption spectrum at 447 and $470-471 \mathrm{~nm}$ and with a slight inflexion at $424-427 \mathrm{~nm}$. Detailed phenotypic properties are summarized in Table 1 and the species description.

Strain $5715 \mathrm{~S}-12^{\mathrm{T}}$ contained ubiquinones that consisted mainly of ubiquinone $10(\mathrm{Q}-10)$. Strain $5715 \mathrm{~S}-12^{\mathrm{T}}$ revealed a complex polar lipid pattern, including diphosphatidylglycerol, phosphatidylmonomethylethanolamine, phosphatidylethanolamine, phosphatidyldimethylethanolamine,

Table 1. Phenotypic characteristics of strain $5715 \mathrm{~S}-12^{\top}$ and the type strains of Aurantimonas species and F. pelagi

Strains: 1, strain $5715 S-12^{\mathrm{T}}$ (data from this study); 2, A. coralicida DSM $14790^{\mathrm{T}}$ (unless indicated, data from Denner et al., 2003); 3, A. altamirensis $\mathrm{S}_{2} 1 \mathrm{~B}^{\mathrm{T}}$ (Jurado et al., 2006); 4, F. pelagi DSM $15513^{\mathrm{T}}$ (Cho \& Giovannoni, 2003). All strains are strictly aerobic and positive for catalase, oxidase and urease. All strains are negative for nitrate reduction, indole production, glucose fermentation, arginine dihydrolase and hydrolysis of aesculin and gelatin. All strains are positive for alkaline phosphatase, esterase (C4), leucine arylamidase and naphthol-AS-BI-phosphohydrolase and negative for lipase (C14), valine arylamidase, cystine arylamidase, trypsin, $\alpha$-chymotrypsin, $\alpha$-galactosidase, $\beta$-galactosidase, $\beta$-glucuronidase, $\beta$-glucosidase, $N$-acetyl- $\beta$-glucosaminidase, $\alpha$-mannosidase and $\alpha$-fucosidase. All strains except F. pelagi DSM $15513^{\mathrm{T}}$ assimilate D-glucose, D-mannose and malic acid and do not assimilate capric acid, adipic acid or trisodium citrate (not reported for F. pelagi DSM $15513^{\mathrm{T}}$ ). +, Positive; w, weak; -, negative; ND, no data available.

\begin{tabular}{|c|c|c|c|c|}
\hline Characteristic & 1 & 2 & 3 & 4 \\
\hline Source & Air & Marine & Cave & Marine \\
\hline Flagellation & $>1$, polar & $>1$, polar & - & - \\
\hline Colony colour & Yellow & Golden orange & Yellow & Brownish yellow \\
\hline Growth in the absence of $\mathrm{NaCl}$ & + & - & + & $\mathrm{W}$ \\
\hline Growth at $10 \%(\mathrm{w} / \mathrm{v}) \mathrm{NaCl}$ & - & - & - & + \\
\hline PHB formation & + & $+^{*}$ & $+^{*}$ & - \\
\hline \multicolumn{5}{|l|}{ Assimilation of: } \\
\hline L-Arabinose & + & $+^{*}$ & $+^{*}$ & - \\
\hline D-Mannitol & + & $-{ }^{*}$ & $-{ }^{*}$ & - \\
\hline $\mathrm{N}$-Acetylglucosamine & - & $-{ }^{\star}$ & $+^{*}$ & + \\
\hline D-Maltose & - & $-{ }^{*}$ & $+^{*}$ & + \\
\hline Potassium gluconate & - & $+^{*}$ & $+^{*}$ & ND \\
\hline Phenylacetic acid & - & $-{ }^{*}$ & $-{ }^{*}$ & + \\
\hline \multicolumn{5}{|l|}{ Activity of: } \\
\hline Esterase lipase (C8) & + & $+^{*}$ & $-{ }^{*}$ & $+^{*}$ \\
\hline Acid phosphatase & + & $-{ }^{*}$ & $+^{*}$ & $-{ }^{*}$ \\
\hline$\alpha$-Glucosidase & - & $-{ }^{*}$ & $-{ }^{*}$ & $+^{*}$ \\
\hline DNA G $+C$ content $(\mathrm{mol} \%)$ & 67.0 & 66.3 & 71.8 & $57.6-59.9$ \\
\hline
\end{tabular}

${ }^{\star}$ Data from this study. 
Table 2. Cellular fatty acid compositions of strain $5715 \mathrm{~S}-12^{\top}$ and the type strains of Aurantimonas species and F. pelagi

Strains: 1, strain $5715 \mathrm{~S}-12^{\mathrm{T}} ; 2$, A. coralicida DSM $14790^{\mathrm{T}} ; 3$, A. altamirensis $\mathrm{S}_{21 \mathrm{~B}^{\mathrm{T}}} ; 4, F$. pelagi DSM $15513^{\mathrm{T}}$. Data were obtained in this study and are percentages of total fatty acids. Fatty acids representing less than $1.0 \%$ in all strains were omitted.

\begin{tabular}{|lcccc|}
\hline Fatty acid & $\mathbf{1}$ & $\mathbf{2}$ & $\mathbf{3}$ & $\mathbf{4}$ \\
\hline $\mathrm{C}_{16: 0}$ & 9.0 & 5.2 & 8.0 & 2.6 \\
$\mathrm{C}_{16: 0} 2-\mathrm{OH}$ & - & 2.9 & - & - \\
$\mathrm{C}_{16: 0} 3-\mathrm{OH}$ & 1.3 & - & - & - \\
$\mathrm{C}_{18: 1} \omega 7 c$ & 62.2 & 61.8 & 72.9 & 80.1 \\
$\mathrm{C}_{18: 1} \omega 5 c$ & - & 2.1 & - & - \\
$\mathrm{C}_{18: 0}$ & 1.1 & 3.2 & 1.0 & 11.2 \\
$\mathrm{C}_{18: 1} 2-\mathrm{OH}$ & 12.7 & 3.2 & 5.7 & - \\
$\mathrm{C}_{18: 0} 3-\mathrm{OH}$ & 1.4 & 1.2 & 1.1 & - \\
$\mathrm{C}_{19: 0}$ cyclo $\omega 8 c$ & 1.6 & 11.0 & 7.8 & 3.1 \\
$\mathrm{C}_{20: 1} \omega 7 c$ & - & 1.0 & - & 2.1 \\
Summed feature $2^{*}$ & 3.9 & - & 2.1 & - \\
Summed feature $3 *$ & 6.9 & - & 1.0 & - \\
Summed feature $5^{*}$ & - & 5.8 & - & - \\
\hline
\end{tabular}

*Summed feature 2 comprises $\mathrm{C}_{14: 0} 3-\mathrm{OH}$ and/or iso- $\mathrm{C}_{16: 1} \mathrm{I}$, summed feature 3 comprises iso- $\mathrm{C}_{15: 0} 2-\mathrm{OH}$ and/or $\mathrm{C}_{16: 1} \omega 7 c$ and summed feature 5 comprises $\mathrm{C}_{18: 2} \omega 6,9 c$ and/or anteiso- $\mathrm{C}_{18: 0}$.

phosphatidylglycerol, phosphatidylcholine and four unknown lipids (Supplementary Fig. S2 available in IJSEM Online). Its polar lipid pattern was generally similar to those of A. coralicida DSM $14790^{\mathrm{T}}$ and Fulvimarina pelagi DSM $15513^{\mathrm{T}}$ except for some minor unknown lipids. Strains $5715 \mathrm{~S}-12^{\mathrm{T}}$ and $A$. coralicida DSM $14790^{\mathrm{T}}$ can be differentiated from F. pelagi DSM $15513^{\mathrm{T}}$ by the presence of the unknown lipid L3 and a larger amount of phosphatidylmonomethylethanolamine. The major fatty acid was $\mathrm{C}_{18: 1} \omega 7 c(62.2 \%)$, and moderate amounts of $\mathrm{C}_{18: 1}$ 2-OH $(12.7 \%), \mathrm{C}_{16: 0}(9.0 \%)$ and summed feature 3 (iso$\mathrm{C}_{15: 0} 2-\mathrm{OH}$ and/or $\left.\mathrm{C}_{16: 1} \omega 7 c\right)(6.9 \%)$ were also detected
(Table 2). The fatty acid profile of strain $5715 \mathrm{~S}-12^{\mathrm{T}}$ was similar to that of $A$. altamirensis $\mathrm{S}_{2} 1 \mathrm{~B}^{\mathrm{T}}$ except for the presence of a small amount $(1.3 \%)$ of $\mathrm{C}_{16: 0} 3-\mathrm{OH}$ in the former strain (Table 2). The DNA $\mathrm{G}+\mathrm{C}$ content was $67.0 \mathrm{~mol} \%$.

A total of 1398 nucleotides from the 16S rRNA gene sequence of strain $5715 \mathrm{~S}-12^{\mathrm{T}}$ were used in the phylogenetic analysis. Comparison of the 16S rRNA gene sequence of strain $5715 \mathrm{~S}-12^{\mathrm{T}}$ with homologous sequences of some members of the order Rhizobiales demonstrated that strain $5715 \mathrm{~S}-12^{\mathrm{T}}$ was closely related to A. altamirensis $\mathrm{S}^{2} 1 \mathrm{~B}^{\mathrm{T}}$ (95.9\% sequence similarity), A. coralicida $\mathrm{WP}^{\mathrm{T}}$ (95.4\%), Ensifer fredii LMG $6217^{\mathrm{T}}(93.6 \%)$, Mycoplana dimorpha IAM $13154^{\mathrm{T}}$ (93.3\%), Mesorhizobium loti LMG $6125^{\mathrm{T}}(92.9 \%)$ and F. pelagi HTCC2506 ${ }^{\mathrm{T}}(92.8 \%)$. A neighbour-joining tree (Fig. 1) shows that strain $5715 \mathrm{~S}-12^{\mathrm{T}}$ forms a cluster with the two Aurantimonas species and $F$. pelagi. According to the maximum-parsimony tree (Supplementary Fig. S3 available in IJSEM Online), strain $5715 \mathrm{~S}-12^{\mathrm{T}}$ was grouped with $A$. altamirensis $\mathrm{S} 21 \mathrm{~B}^{\mathrm{T}}$ within the genus Aurantimonas clade. Based on these results, it is concluded that strain $5715 \mathrm{~S}-12^{\mathrm{T}}$ represents a novel species of the genus Aurantimonas, for which the name Aurantimonas ureilytica sp. nov. is proposed.

\section{Description of Aurantimonas ureilytica sp. nov.}

Aurantimonas ureilytica (ur.e.i.ly'ti.ca. N.L. n. urea urea; N.L. fem. adj. lytica from Gr. adj. lutikos dissolving; N.L. fem. adj. ureilytica urea-dissolving).

Cells are motile, Gram-negative, non-spore-forming, short rods $(1.0-1.5 \mu \mathrm{m}$ wide and $1.5-2.5 \mu \mathrm{m}$ long). Strictly anaerobic and catalase- and oxidase-positive. The ranges (optima) of temperature, $\mathrm{pH}$ and $\mathrm{NaCl}$ concentration for growth are $4-37{ }^{\circ} \mathrm{C}\left(25-30{ }^{\circ} \mathrm{C}\right), \mathrm{pH} 4-9$ ( $\left.\mathrm{pH} 7-8\right)$ and 0-3\%. Negative for nitrate reduction, indole production, glucose fermentation and arginine dihydrolase. Cells hydrolyse starch, Tween 80 and urea, but not aesculin,

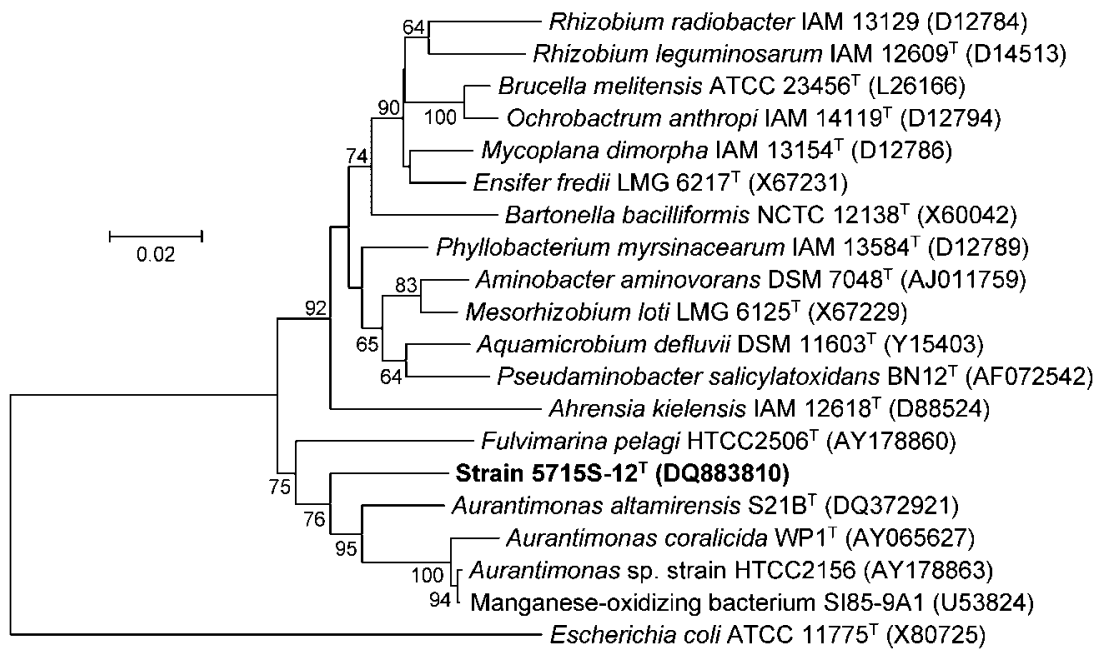

Fig. 1. Neighbour-joining tree showing the phylogenetic positions of strain $5317 \mathrm{~S}-12^{\top}$ and related taxa based on 16S rRNA gene sequences. Numbers at nodes are levels of bootstrap support (\%) based on neighbourjoining analyses of 1000 resampled datasets; only values above $60 \%$ are given. Bar, 0.02 substitutions per nucleotide position. 
casein, chitin, CM-cellulose, DNA, gelatin, pectin or tyrosine. According to API 20NE and API ID 32GN test strips, D-glucose, L-arabinose, D-mannose, D-mannitol, malic acid, L-rhamnose, D-ribose, inositol, sucrose, sodium acetate, lactic acid, L-alanine, potassium 5-ketogluconate, glycogen, D-melibiose, L-fucose, D-sorbitol, propionic acid, valeric acid, potassium 2-ketogluconate, 3-hydroxybutyric acid and 4-hydroxybenzoic acid are assimilated. Does not assimilate $\mathrm{N}$-acetylglucosamine, maltose, potassium gluconate, capric acid, adipic acid, trisodium citrate, phenylacetic acid, itaconic acid, suberic acid, sodium malonate, 3-hydroxybenzoic acid, L-serine, salicin, L-histidine or L-proline. According to API ZYM test strips, positive for activities of alkaline phosphatase, esterase (C4), esterase lipase (C8), leucine arylamidase, acid phosphatase and naphthol-AS-BI-phosphohydrolase and negative for activities of lipase (C14), valine arylamidase, cystine arylamidase, trypsin, $\alpha$-chymotrypsin, $\alpha$-galactosidase, $\beta$-galactosidase, $\beta$-glucuronidase, $\alpha$-glucosidase, $\beta$-glucosidase, $N$-acetyl $-\beta$ glucosaminidase, $\alpha$-mannosidase and $\alpha$-fucosidase. The major fatty acid is $\mathrm{C}_{18: 1} \omega 7 c$. The predominant isoprenoid quinone is $\mathrm{Q}-10$. The DNA G $+\mathrm{C}$ content of the type strain is $67.0 \mathrm{~mol} \%$.

The type strain is $5715 \mathrm{~S}-12^{\mathrm{T}}\left(=\mathrm{KACC} 11607^{\mathrm{T}}=\mathrm{DSM}\right.$ $\left.18598^{\mathrm{T}}\right)$, isolated from air in the Republic of Korea.

\section{Acknowledgements}

This work was supported by the Agricultural Research \& Promotion Center, Republic of Korea.

\section{References}

Cho, J. C. \& Giovannoni, S. J. (2003). Fulvimarina pelagi gen. nov., sp. nov., a marine bacterium that forms a deep evolutionary lineage of descent in the order 'Rhizobiales'. Int J Syst Evol Microbiol 53, 1853-1859.

Denner, E. B. M., Smith, G. W., Busse, H.-J., Schumann, P., Narzt, T., Polson, S. W., Lubitz, W. \& Richardson, L. L. (2003). Aurantimonas coralicida gen. nov., sp. nov., the causative agent of white plague type II on Caribbean scleractinian corals. Int J Syst Evol Microbiol 53, 1115-1122.

Groth, I., Schumann, P., Weiss, N., Martin, K. \& Rainey, F. A. (1996). Agrococcus jenensis gen. nov., sp. nov., a new genus of actinomycetes with diaminobutyric acid in the cell wall. Int J Syst Bacteriol 46, 234-239.

Jurado, V., Gonzalez, J. M., Laiz, L. \& Saiz-Jimenez, C. (2006). Aurantimonas altamirensis sp. nov., a member of the order Rhizobiales isolated from Altamira Cave. Int J Syst Evol Microbiol 56, 2583-2585.

Kumar, S., Tamura, K. \& Nei, M. (2004). MEGA3: integrated software for molecular evolutionary genetics analysis and sequence alignment. Brief Bioinform 5, 150-163.

Mesbah, M., Premachandran, U. \& Whitman, W. B. (1989). Precise measurement of the $\mathrm{G}+\mathrm{C}$ content of deoxyribonucleic acid by highperformance liquid chromatography. Int J Syst Bacteriol 39, 159-167.

Minnikin, D. E., O’Donnell, A. G., Goodfellow, M., Alderson, G., Athalye, M., Schaal, A. \& Parlett, J. H. (1984). An integrated procedure for the extraction of bacterial isoprenoid quinones and polar lipids. J Microbiol Methods 2, 233-241.

Sasser, M. (1990). Identification of bacteria by gas chromatography of cellular fatty acids. Technical Note no. 101. Newark, DE: MIDI Inc.

Smibert, R. M. \& Krieg, N. R. (1994). Phenotypic characterization. In Methods for General and Molecular Bacteriology, pp. 607-654. Edited by P. Gerhardt, R. G. E. Murray, W. A. Wood \& N. R. Krieg. Washington, DC: American Society for Microbiology. 